\title{
The effects of groundwater discharge, mowing and eutrophication on fen vegetation evaluated over half a century
}

\author{
van Belle, Jasper ${ }^{1, *}$; Barendregt, Aat ${ }^{1,2}$ \& Schot, Paul P. ${ }^{1,3}$; Wassen, Martin J. .,4 \\ ${ }^{1}$ Environmental Sciences, Copernicus Institute, Utrecht University, P.O. Box 80.115, 3508 TC Utrecht, The Netherlands; \\ ${ }^{2}$ E-mail a.barendregt@geo.uu.nl; ${ }^{3} E$-mailp.schot@geo.uu.nl; ${ }^{4} E$-mailm.wassen@geo.uu.nl; \\ ${ }^{*}$ Corresponding author; E-mail j.vanbelle@geo.uu.nl
}

\begin{abstract}
Questions: Were continued groundwater discharge and mowing regimes sufficient for vegetation preservation from 1944 to 1993 ? Which has a stronger effect on vegetation development; groundwater discharge or mowing? What is the role of surface water eutrophication as driver of vegetation change? Location: Het Hol, The Netherlands (ca. 92 ha, 52 ${ }^{\circ} 13^{\prime} \mathrm{N}$, $\left.5^{\circ} 05^{\prime} \mathrm{E}\right)$.

Methods: Hydrology was simulated for the late 1940s, early 1960s and 1987. Vegetation maps (1944, 1960, 1975 and 1993) were compared for biotope cover. Vegetation recordings in 1944 and 1987 were compared. Surface water quality was compared between 1950 and 1987. Which sites were mown was reconstructed from an interview. Effects of periodic mowing and groundwater discharge on vegetation development were tested for correlation.

Results: Biotope diversity reduced significantly through decrease of semi-aquatic and tall-herb biotopes, and expansion of forest. The quagfen terrestrialization sere nearly disappeared from 1987 recordings, while the reed sere did well concerning abundance and species richness. Several typical (rich) fen species disappeared from recordings, while new species were mostly field margin species. Periodic mowing and discharge combined are correlated with increasing species numbers. The P-concentration in surface water increased while $\mathrm{N}$-concentration decreased.

Conclusions: Preservation of the reed sere was successful, whereas preservation of the quagfen sere was not. Periodic mowing and discharge stimulate species richness, discharge more so than periodic mowing. But slight eutrophication likely induced a shift from P-limitation to N-limitation, which stimulated the reed sere at the expense of the quagfen sere.
\end{abstract}

Keywords: Eutrophication; Fen conservation; N-limitation; P-limitation; Rich fen; Succession; Terrestrialization.

Nomenclature: Phanerogams: van der Meijden (1996); Bryophytes except Sphagna: Margadant \& During (1982); Sphagna: Bouman (2002); Syntaxa: Schaminée et al. (19951999).

\section{Introduction}

Fens have a high biodiversity as a result of biotope diversity and the species-rich vegetation of some of these biotopes (den Held et al. 1992; Wheeler 1993). Biotope diversity stems from terrestrialization, the transformation of water to land by peat accumulation under oxygen-poor water-logged conditions (Pons 1992). In freshwater fens two terrestrialization seres can be identified, (1) the eutrophic reed sere, with different, successionally related, types of reed vegetation, and (2) the mesotrophic quagfen sere (van Wirdum et al. 1992). The latter resembles the Cladium sere (Giller \& Wheeler 1986), and includes rich fen vegetation (Sjörs 1950), which is base-rich and species-rich, and contains rarities (den Held et al. 1992; Wheeler 1993). However, in NWEurope fens, especially rich fens, are deteriorating (e.g. Kooijman 1992), which is attributed to changes in hydrology, termination of mowing, eutrophication, acidification, and $\mathrm{NH}_{4}{ }^{+}$-poisoning of rich fen mosses.

The effects of these different drivers for vegetation preservation can only be assessed using data sets that span decades, since terrestrialization and succession proceed at this scale. Fojt \& Harding (1995) studied fen vegetation change over 32 years in the UK, which they related to changes in mowing regime and hydrology. They found that both mowing regime and hydrology are important, but "changes in hydrology cannot be compensated for by increased management". This is in accordance with findings of van Diggelen et al. (1996) in a study of a Dutch fen covering 33 years. They found that differences in mowing regime lead to different succession seres if starting conditions are equal, but different starting conditions can only temporarily be compensated for with mowing. Barendregt et al. (1990) reconstructed vegetation change in the river plain of the Dutch River Vecht from 1872 to 1987, which they related to changes in ground- and surface water tables, flows, and -chemistry. They found that supply of eutrophic water from the River Vecht, in order to compensate for reduced inflow from groundwater, changed the 
surface-water chemistry. This led to the disappearance of aquatic vegetation and initial stages of terrestrialization, which interrupted succession. Other known sources of eutrophication are atmospheric deposition of $\mathrm{N}$, run-off to surface water of fertilizer (Verhoeven et al. 1993), and internal eutrophication.

Internal eutrophication refers to two separate processes: (1) supply of $\mathrm{HCO}_{3}$-rich water, leads to alkalinization, and (2) supply of $\mathrm{SO}_{4}$-rich water increases $\mathrm{SO}_{4}$ reduction to $\mathrm{HS}^{-}$. Both processes increase $\mathrm{PO}_{4}$ mobilisation (Roelofs 1991; Lamers et al. 1998). Acidification can result from increased atmospheric deposition (Hogg et al. 1995), from a lowered groundwater table (Schot et al. 2004), or from succession (Godwin \& Turner 1933).

Poisoning of rich fen mosses through atmospheric $\mathrm{NH}_{\mathrm{y}}$ deposition stems from toxicity of free $\mathrm{NH}_{4}{ }^{+}$(Britto et al. 2001). Paulissen et al. (2004) showed that Dutch $\mathrm{NH}_{\mathrm{y}}$ deposition levels (Eerens et al. 2001) during the 1980s and 1990s reduced the growth of Scorpidium scorpioides, whereas its successors Sphagnum squarrosum and Polytrichum commune are not affected. This interspecific difference in response to $\mathrm{NH}_{4}{ }^{+}$could imply an acceleration of succession from rich fen to poor fen, and promote development of species-poor derivative communities.

The plain of the River Vecht has been recognized for its high floristic value since the early 20 th century. The area 'Het Hol' drew particular attention, mainly because of its well-developed rich fen vegetation (Meijer \& de Wit 1955). The special characteristics of Het Hol are thought to stem from its isolated hydrological position combined with groundwater discharge, which reduces the impact of polluted water from the River Vecht (Meijer \& de Wit 1955; Anon. 1996). Between 1947 and 1949 the Dutch Society for the Preservation of Nature acquired Het Hol (Gorter 1956). They initiated nature conservation, consisting of continuation of mowing regimes (where feasible) and closing the area to recreation.

Because of its floristic value Het $\mathrm{Hol}$ has been the subject of several floristic and some hydrochemical investigations. The availability of these data enabled us to assess how well vegetation has been preserved between World War II and the 1990s, and how this relates to known drivers of vegetation change. If Het $\mathrm{Hol}$ is isolated from supply water and has unchanged groundwater discharge, ongoing succession would have increased the proportion of forest in Het Hol somewhat. But, as long as there is water in which initial stages can develop, we expect the full range of vegetation types belonging to the quagfen sere to occur. First, we show that groundwater discharge is preserved. Next, we assess whether continued discharge and maintained mowing regimes are sufficient for long-term vegetation preservation, and whether groundwater discharge or mowing has a stronger positive effect on vegetation change and species richness. Finally, we assess the role of surface water eutrophication as driver of deterioration.

\section{Study area}

Het Hol (ca. 92 ha) is part of the plain of the River Vecht which stretches west from the foot of a push moraine in the Gooi region, north of Utrecht, The Netherlands $\left(52^{\circ} 07^{\prime}-52^{\circ} 20^{\prime} \mathrm{N}\right.$ and $\left.5^{\circ} 02^{\prime}-5^{\circ} 18^{\prime} \mathrm{E}\right)$. See Schot \& Molenaar (1992) for a detailed description. N-deposition in The Netherlands has been severe, reaching a maximum of 76 $\mathrm{kg} \cdot \mathrm{ha}^{-1} \cdot \mathrm{a}^{-1}$ in 1987 (Eerens et al. 2001), but is decreasing. Fig. 1 shows the study area, surrounding polders which are management units for water boards, and the locations of cross-sections used in hydrological reconstructions.

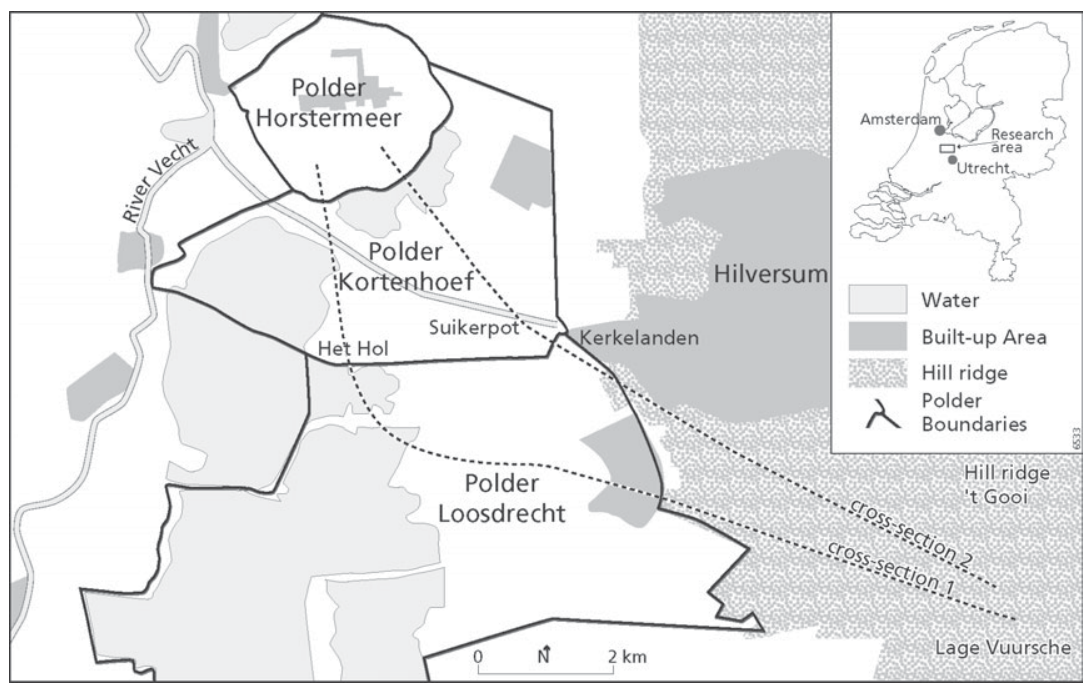

Fig. 1. Map of the research area Het Hol, and its surroundings, central Netherlands. Also shown are polders and cross-sections used in hydrological simulations. 
Peat, which developed on the Pleistocene sands, was cut and dredged from the 16th century onwards to be used for fuel in the nearby cities (de Smidt et al. 1979). This procedure resulted in a pattern with long, narrow, and shallow turf ponds, which were separated by narrow strips of uncut peat (de Smidt et al. 1979). Locally, wave action destroyed these strips, which resulted in the present-day landscape of shallow lakes and turf ponds. Furthermore, 19th century reclamation of lakes, groundwater abstraction in the hill ridge since 1888, and 20th century construction of canals had significant effects on groundwater flows (Schot \& Molenaar 1992). Surface water level management of polders involved the pumping of excess water (rain water and discharging groundwater) in winter and spring, and the supply of water from the River Vecht during dry periods in summer. The study area Het $\mathrm{Hol}$ is located in the polder Kortenhoef (Fig. 1). Groundwater is recharged by infiltrating rain water in the hill ridge and discharges in the east of Kortenhoef. West of Kortenhoef the water flow is downward towards the adjacent reclaimed lake Horstermeer, with a surface water level ca. 2 m lower than Kortenhoef. Het Hol is influenced by inflow of surface water from the Suikerpot area to the east (where regional groundwater discharges). Presumably, water from the lakes in the polder Loosdrecht discharges in the south of Het Hol, because surface water levels in the polder Loosdrecht are kept higher than in the polder Kortenhoef.

\section{Methods}

\section{Hydrology}

To determine whether the hydrological system was indeed unchanged, groundwater flow patterns were simulated in the two-dimensional stationary groundwater model FLOWNET (van Elburg et al. 1989) for the late 1940s and for 1987. A first cross-section was constructed along the main direction of groundwater flow, i.e. perpendicular to hydraulic head contour lines, covering as much of Het $\mathrm{Hol}$ as possible (cross section 1; Fig. 1). Hydraulic heads used in the late-1940s model were polder levels taken from Küppers (1949) in the river plain, and on hydraulic head measurements in the hill ridge in three locations within a $\mathrm{km}$ of the simulated cross-section (data courtesy of TNO-NITG). We determined the average hydraulic head over the summers (April through October) for 1947 and 1948. Data analysis showed this to be a period without anomalies, with hydraulic heads fairly constant relative to each other, while measurements were taken irregularly before 1947 .

East from the Suikerpot, a residential area (Kerkelanden) has been developed since 1965, which possibly influenced hydraulic heads, and thereby discharge in the Suikerpot area. Therefore, a second cross section was constructed running just east of Het Hol, through the Suikerpot area (cross section 2; Fig. 1). Hydraulic head measurements before 1962 were unavailable for the Kerkelanden area, but data analysis showed hydraulic heads near Lage Vuursche on the push moraine had not changed between 1947 and 1965. Therefore, the Flownet simulation was run using hydraulic head data from 19621964 (data courtesy TNO-NITG), with polder level data from Küppers (1963).

Also, in 1987 hydraulic head measurements were performed at 14 locations in and immediately around Het Hol. These were used to divide Het Hol into an area with groundwater discharge in spring ('discharge zone'), and an area with groundwater recharge in spring ('recharge zone').

\section{Changes in biotope pattern between 1944 and 1993}

We reconstructed changes in biotope diversity in Het Hol by comparing four vegetation maps (scales 1:2000 - 1:5000, 5 - 27 vegetation types), which cover the period under review with ca. 15-year intervals. The area was mapped by H.P. Gorter in 1944 (Meijer \& de Wit 1955); in 1960 by H.J.Th. Goos (unpubl.); in 1975 by Bogaers et al. (1976); and in 1993 by M.J. Wassen (unpubl.). We transformed vegetation classes on these maps to the five biotopes used by Gorter; grassland, woodland, open water, semi-terrestrial vegetation, and tall-herb vegetation. Tall-herb vegetation consists of "... accessible areas, not consisting of forest or grassland ..." (pers. comm. H.P. Gorter 1994), i.e. mid-successional herb, reed, and sedge vegetation. The 1960 map is somewhat different from the others in that it leaves several land parcels unmapped. Presumably most of the unmapped area is pasture; therefore we allocate all unmapped area to the grassland class. For each biotope we determined the proportional area by cutting and weighing. Evenness of distribution of cover over the biotopes is calculated using Pielou's transformation of the ShannonWiener index (Zar 1984), which is a relative diversity index ranging from 0 to 1 . Significance of difference between diversity indices is determined using Hutcheson's $t$-test, with a 5\% confidence interval (Zar 1984).

\section{Changes in syntaxa between 1944 and 1987}

Meijer \& de Wit (1955) added site descriptions to their vegetation relevés in Het Hol. Of these, 39 are accurate to the extent that the sites could be traced back with an accuracy of $15 \mathrm{~m}$ (area $3-25 \mathrm{~m}^{2}$ ). These sites were recorded anew in 1987 by M.J. Wassen $\left(10 \mathrm{~m}^{2}\right)$, if the site harboured multiple types of vegetation the 
vegetation that corresponded best to that sampled in 1944 was recorded. In the relevés by Meijer \& de Wit (1955) the alpha-numerical scale of Braun-Blanquet, was used; we transform this to the fully numerical ordinal scale of van der Maarel (1979). The 1987 relevés were based on this scale. The 1944 and 1987 recordings were combined in one database, which was clustered using FLEXCLUS (van Tongeren 1986).

In order to calculate the average cover per cluster for each species, the van der Maarel-scale was transformed to mean cover percentage values, according to van der Maarel (1979). These values were averaged over the non-zero records in the cluster. The relative frequency of a species in a cluster was calculated by dividing the number of non-zero records (in a cluster) for a species by the total number of records in the cluster. Trophic status is based on Schaminée et al. (1995-1999), with the exception of pasture, the trophic status of which was based on expert judgement.

\section{Changes in species composition between 1944 and 1987}

Changes in species composition were determined from the same data set as used for the syntaxa. Average cover- and relative frequency over all records were calculated for each year according to the methodology described for clusters (substituting year for cluster). Species are ordered according to their typical habitat in the study region. The Dutch Red List status was determined from Siebel \& Bijlsma (2004) for mosses, and from van der Meijden et al. (2000) for vascular plants.

\section{Effect of periodic mowing and discharge on vegetation development}

We investigated the influence of periodic mowing and groundwater discharge on vegetation development on 27 (semi-)terrestrial, non-forest sites. For each site we listed whether it was situated in the groundwater discharge-, or recharge zone. On 30.10.2000 Mr. P. Honig, a retired ranger formerly employed in Het Hol, was interviewed to determine which sites were mown. Next, for each site the vegetation clusters in 1944 and in 1987 were determined, as well as the number of species in each respective recording. For each site we listed whether or not vegetation had changed cluster status, and whether the number of species had declined, remained the same, or increased. These four factors, i.e. groundwater discharge $(-1$ or 1$)$, mowing regime $(-1$ or 1$)$, change in vegetation type $(-1$ or 1$)$, and change in number of species $(-1,0$ or 1$)$ were tested for association in SPSS (Anon. 2002), using Pearson's $\chi^{2}$ for significance, and $\phi$ or Cramer's $V$ for correlations.

\section{Surface water composition}

De Graaf (in Meijer \& de Wit 1955) presented chemical analyses of water from two of the main lakes in Het Hol, averaged over the period March through October 1950. One of these lakes was sampled again during the summer of 1987 (see Wassen et al. 1989 for a description of analytical methods). Results from bimonthly samples taken from March - October 1987 were averaged and compared with the 1950 results.

\section{Results}

Hydrology

Fig. 2 shows groundwater fluxes along cross-section 1, as simulated by FLOWNET for 1987. Groundwater infiltrates in the hill-ridge, and flows to the polder area through the deep soil. Most of it discharges at the foot of the hill-ridge (in polder Loosdrecht). Closer to the polder Horstermeer groundwater is recharged by infiltrating surface water, and discharges in polder Horstermeer (see Fig. 1 for polder locations). The difference in hydraulic head over the entire cross-section is ca. 4.65 m. Discharge-water in Het $\mathrm{Hol}$ infiltrated in polder

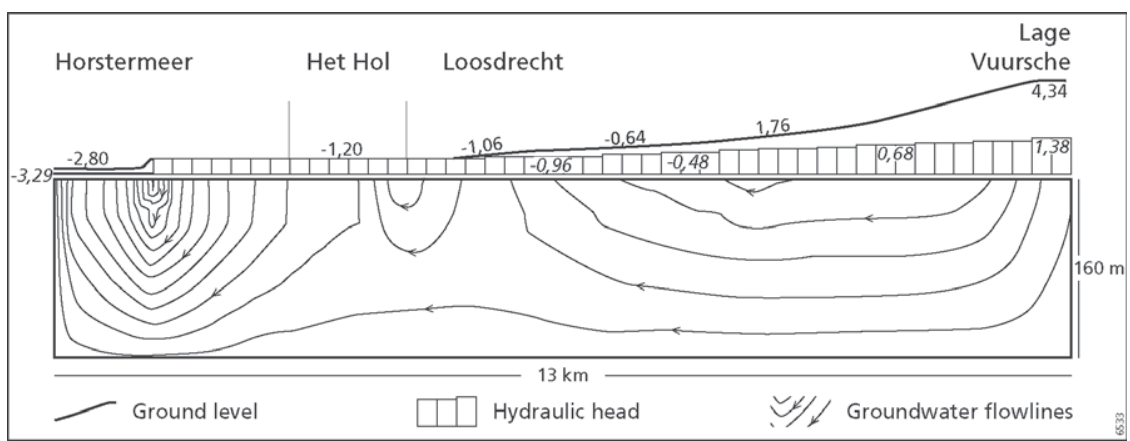

Fig. 2. FLOWNET simulation of groundwater flow patterns in cross-section 1 in 1987. Ground levels, hydraulic heads, and polder water levels are indicated in meters relative to the Dutch reference level (NAP). 
Loosdrecht, therefore discharge in Het Hol is determined by differences in surface water level between polders Loosdrecht and Kortenhoef, which increased from $10 \mathrm{~cm}$ in the $1940 \mathrm{~s}$ to $14 \mathrm{~cm}$ in 1987. FLOWNET simulations and 1987 hydraulic head measurements indicate groundwater discharge in Het $\mathrm{Hol}$ is restricted to the southernmost 200-300 m. Flownet simulation showed that groundwater fluxes to and from Het Hol along cross-section 1 did not change appreciably between the 1940s and 1987, even though hydraulic heads in the hill ridge dropped some $30 \mathrm{~cm}$.

The hydrological system in cross-section 2 for 1987 , as simulated by FLOWNET, is very similar to that of cross-section 1 for 1987. The Suikerpot area is located at the foot of the hill-ridge, where groundwater discharges. Comparison of the early 1960s simulation with that of 1987 indicates that groundwater discharge has decreased in Suikerpot area, hydraulic heads in the hill ridge dropped $30 \mathrm{~cm}$, and hydraulic heads in Kerkelanden area dropped 10-15 cm. Decreased groundwater discharge in Suikerpot area presumably reduced lateral surface water flow towards Het Hol.

\section{Changes in biotope pattern between 1944 and 1993}

Fig. 3 shows the changes in biotope diversity as percentage cover per biotope for the years 1944, 1960, 1975 and 1993. The biotope grassland shows a 24\% decrease, water a $37 \%$ decrease, semi-aquatic vegetation a $50 \%$ decrease, and tall-herb vegetation a $97 \%$ decrease. On the other hand, woodland showed a $191 \%$ increase.

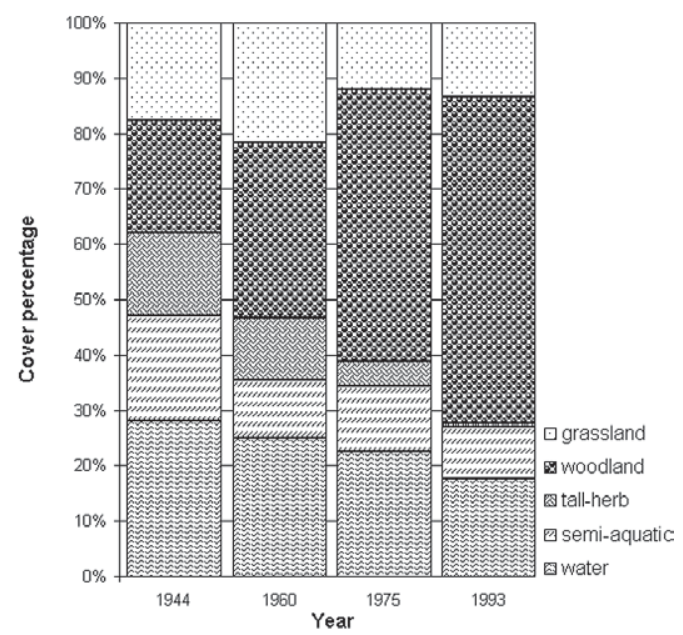

Fig. 3. Proportional area (as percentage of total area) of the biotopes water, semi-aquatic vegetation, tall-herb vegetation, woodland and grassland. Based on the 1944 map from Meijer $\&$ de Wit (1955), the 1960-map from Goos (unpubl.), the 1975-map from Bogaers et al. (1976), and a 1993-map based on own observations.
Evenness in biotope distribution steadily decreased from 1944 to 1993 from 0.99 to 0.71 . Shannon-Wiener diversity is lower in 1975 and in 1993 than in 1944 and $1960\left(P_{1944 \text { vs } 1975}<0.001 ; P_{1944 \text { vs } 1993}<0.0001 ; P_{1960 \text { vs }}\right.$

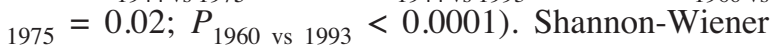
diversity in 1944 is not significantly different from 1960 $(P=0.16)$, nor is 1975 different from $1993(P=0.07)$.

\section{Changes in syntaxa between 1944 and 1987}

FLEXCLUS identified 15 clusters, five of which are based on a single vegetation relevé. Of the ten clusters including multiple relevés eight fit the syntaxonomical classification of Schaminée et al. (1995-1999), and these are named accordingly. One of the two remaining clusters resembles vegetation described by Westhoff et al. (1971) as a successional precursor of quagfen vegetation. We refer to this Equisetum fluviatile - Carex rostrata dominated vegetation as embryonic quagfen. The second remaining cluster we identify as acidified reedland, dominated by Phragmites australis and Sphagnum palustre. One of the single-relevé clusters was identifiable as bog vegetation (resembling Sphagno palustrisEricetum), and one as pasture. The remaining three clusters were allocated to a class 'miscellaneous'. The vegetation types are summarized in a synoptic table (App. 1).

While ignoring the miscellaneous class, four vegetation types newly appeared, four increased in abundance, three decreased, and one type disappeared (Table 1). Mesotrophic Scorpidio-Caricetum diandrae vegetation disappeared, while its successional precursor, embryonic quagfen, and its successor, Pallavicinio-Sphagnetum, both decreased in abundance. Meso- to eutrophic Cladietum marisci vegetation slightly decreased in abundance. Typho-Phragmitetum typhetosum angustifoliae, a meso- to eutrophic semi-aquatic vegetation, and acidified reedland, newly appeared. Also new are Sphagno palustris-Ericetum, a late-successional, oligotrophic bog vegetation, and pasture. The latter results from land use change at one of the sites. Of the increasing types two are meso- to eutrophic semi-aquatic types (Stratiotetum and Cicuto-Caricetum pseudocyperi), and one is late successional meso- to eutrophic alder carr (ThelypteridoAlnetum). This leaves the slightly increasing type TyphoPhragmitetum thelypteridetosum, a mid-successional meso- to eutrophic type.

In 1944 the most species-rich vegetation type was Pallavicinio-Sphagnetum, followed by Typho-Phragmitetum thelypteridetosum, Thelypterido-Alnetum and Scorpidio-Caricetum diandrae. In 1987 the most speciesrich vegetation type was the Typho-Phragmitetum thelypteridetosum, followed by the Cicuto-Caricetum pseudocyperi, and Sphagno palustris-Ericetum. PallavicinioSphagnetum and Thelypterido-Alnetum were no longer 
Table 1. Trends in vegetation types as distinguished by FLEXCLUS, and number of relevés $\left(n_{\text {rel }}\right)$ allocated to each type for 1944 and 1987. Mean number of species $\left(m_{\text {spec }}\right)$ is the arithmetic mean of all yearly relevés of each type.

\begin{tabular}{lcccc}
\hline Vegetation type & $n_{\text {rel }} 1944$ & $n_{\text {rel }} 1987$ & $m_{\text {spec }} 1944$ & $m_{\text {spec }} 1987$ \\
\hline Scorpidio-Caricetum diandrae & 8 & - & 26.3 & - \\
Pallavicinio-Sphagnetum & 4 & 1 & 30.0 & 18.0 \\
Embryonic quagfen & 4 & 1 & 16.8 & 12.0 \\
Cladietum marisci & 3 & 2 & 11.7 & 11.5 \\
Typho-Phragmitetum thelypteridetosum & 7 & 8 & 28.7 & 26.1 \\
Stratiotetum & 4 & 6 & 9.3 & 12.5 \\
Cicuto-Caricetum pseuodcyperi & 3 & 6 & 25 & 25.5 \\
Thelypterido-Alnetum & 4 & 7 & 26.8 & 15.0 \\
Sphagno palustris-Ericetum & - & 1 & - & 25.0 \\
Typho-Phragmitetum typhetosum angustifoliae & - & 2 & - & 13.5 \\
Acidified reed land & - & 3 & - & 19.3 \\
Pasture & - & 1 & - & 22.0 \\
\hline
\end{tabular}

among the most diverse vegetation types in 1987, although they were still present; both decreased in species richness to a medium level. Typho-Phragmitetum thelypteridetosum, the most species-rich type in 1987, only slightly changed in species richness. CicutoCaricetum pseudocyperi and Cladietum marisci showed no change in species richness. Stratiotetum vegetation showed an increase in species richness, while the remaining four types showed a decrease in species richness.

\section{Changes in species composition between 1944 and 1987}

App. 2 lists vascular- and non-vascular plant species that were recorded in 1944, but not in 1987. In total one stonewort, 19 mosses, and 19 vascular plant species were lost from the data set. App. 3 lists species that were recorded in 1987, but were not recorded in 1944. Seven moss species and 30 vascular plant species newly appeared in the data set. Therefore, total species richness remained constant, with a total of 145 species in 1944 and 143 species in 1987. Of the 39 lost species 13 are species typical of rich fens, six are typical of poor fens, five are typical of meso- to eutrophic aquatic conditions, and six are typical of wet hayfields. Two lost species are Critically Endangered in The Netherlands, one is Endangered, and six are Vulnerable. Of the 37 new species two are typical of fens in general, three are typical of bogs, two are typical of eutrophic aquatic conditions, four trees are typical of carr forest, three mosses live on dead wood, 10 species are typical of fertile grasslands, and eight are typical of field margins. One new species is Endangered and two are Vulnerable.
Effect of periodic mowing and discharge on vegetation development

Twenty sites were situated in the discharge zone, 14 were mown regularly, of which nine within the discharge zone. At 20 sites the vegetation cluster changed between 1944 and 1987, seven sites were unchanged. Nine sites showed an increase in the number of species per recording, four sites showed no change, and 14 showed a decrease in the number of species. Correlations between respectively groundwater discharge or mowing regime and change of vegetation cluster were not significant. But within the discharge zone application of a mowing regime was correlated with an increase in the number of species $(P=0.05, R$ $=0.54)$. In mown sites presence of groundwater discharge was correlated with an increase in the number of species $(P=0.03, R=0.70)$.

\section{Surface water composition}

Table 2 lists surface water ion concentrations in 1950 and in 1987 for lake 'Gat van de Zandheuvel', one of the main lakes in Het Hol. For comparison, water quality from the River Vecht (Barendregt et al. 1993) and average nutrient concentrations of sewage (data courtesy DWR) are listed as well. Acidity of the water increased by a half $\mathrm{pH}$-point, while unchanged $\mathrm{Cl}$ concentrations point to unchanged proportions of ground-, surface-, and rainwater, and limited influence of supply water from the River Vecht (which has much higher chloride concentrations). Decreasing concentrations of $\mathrm{Fe}, \mathrm{HCO}_{3}$, and $\mathrm{Mg}$ indicate decreased input of minerotrophic water. Inorganic $\mathrm{N}\left(\mathrm{NH}_{4}\right.$ and $\left.\mathrm{NO}_{3}\right)$ decreased in concentration, while the concentrations of $\mathrm{PO}_{4}$ and $\mathrm{SO}_{4}$ increased. 
Table 2. Surface water quality March - October in one of the main water bodies, 1950 and 1987. All concentrations are in mg/l; 1950 concentrations are from de Graaf (1955). For comparison water quality of the River Vecht (data from Barendregt et al. 1993) and nutrient content of sewage influent (data courtesy DWR) are listed.

\begin{tabular}{|c|c|c|c|c|c|}
\hline \multirow[b]{2}{*}{ Ion } & \multicolumn{3}{|c|}{ Gat van de Zandheuvel } & \multicolumn{2}{|c|}{ River Vecht } \\
\hline & $\begin{array}{l}1950) \\
(\mathrm{mg} / 1\end{array}$ & $\begin{array}{c}1987 \\
(\mathrm{mg} / \mathrm{l})\end{array}$ & $\begin{array}{c}\text { Change } \\
(\%)\end{array}$ & $\begin{array}{c}1990 \\
(\mathrm{mg} / \mathrm{l})\end{array}$ & $\begin{array}{r}\text { Sewage } \\
(\mathrm{mg} / \mathrm{l})\end{array}$ \\
\hline $\mathrm{pH}$ & 7.75 & 7.23 & * & 7.48 & \\
\hline $\mathrm{Cl}^{-}$ & 72.00 & 74.01 & +3 & 117.45 & $100-200$ \\
\hline $\mathrm{Fe}^{2+\& 3+}$ & 0.18 & 0.12 & -35 & 0.15 & \\
\hline $\mathrm{HCO}_{3}^{-}$ & 113.00 & 81.84 & -28 & 168.10 & \\
\hline $\mathrm{Mg}^{2+}$ & 13.87 & 5.11 & -63 & 8.31 & \\
\hline $\mathrm{Ca}^{2+}$ & 34.31 & 31.69 & -8 & 65.39 & \\
\hline $\mathrm{NO}_{3}^{-}$ & 1.29 & 0.22 & -83 & 4.30 & \\
\hline $\mathrm{NH}_{4}^{+}$ & 0.46 & 0.19 & -60 & 2.60 & \\
\hline $\mathrm{PO}_{4}^{3-}$ & 0.019 & 0.045 & +84 & 3.10 & \\
\hline $\mathrm{SO}_{4}^{2-}$ & 11.40 & 17.59 & +54 & 73.28 & $70-100$ \\
\hline $\mathrm{N}$ total & & & & & $50-70^{* *}$ \\
\hline P total & & & & & $7-10 * *$ \\
\hline $\mathrm{N}: \mathrm{P}$ & 105 & 17 & & 3 & 7 \\
\hline
\end{tabular}

\section{Discussion}

\section{Hydrology}

Our hydrological simulation shows that discharge in Het Hol was not reduced, because it is governed by a local hydrological system superimposed on the regional system. This was not influenced by a $30-\mathrm{cm}$ drop of hydraulic heads in the hill ridge between the late 1940s and 1987. However, discharge in the Suikerpot area was reduced by this drop combined with the construction of a residential area. As a result the total input of minerotrophic surface water into Het Hol will have decreased.

\section{Vegetation preservation}

The biotope pattern showed an increase in grassland area from 1944 to 1960 , followed by a strong decline. Apparently our decision to consider the unmapped parcels in 1960 as grassland was wrong. The decrease in grassland area presumably results from abandonment due to reduced profitability of exploitation. The dominant trend is an increase in carr forest, which probably reflects succession of sites no longer mown.

Another trend is the reduction of early- (semi-terrestrial) vegetation and the disappearance of mid-successional (tall-herb biotope) vegetation. Statistical comparison of cover distributions shows that the diversity was greater in 1944 and in 1960 than it was in 1975 and in 1993, which suggests that a major change occurred between 1960 and 1975. Closer inspection shows that the mesotrophic quagfen sere failed, while the more eutrophic reed sere did well: Comparison of 1944 and 1987 relevés shows that Scorpidio-Caricetum diandrae vegetation disappeared, while its precursor (embryonic quagfen) and its successor (Pallavicinio-Sphagnetum) in terrestrialization were strongly reduced. In contrast, the abundance of species-rich reed vegetation (TyphoPhragmitetum thelypteridetosum) and its species richness remained unchanged, while new appearances of early successional Typho-Phragmitetum typhetosum angustifoliae and mid-successional acidified reedland complete the reed sere.

The balance of lost and gained species illustrates the shift away from the quagfen sere. Of the 39 species lost, 19 are typical of rich or poor fen, including Scorpidium scorpioides, Hammarbya paludosa and three Campylium species. Moreover, five aquatic species were lost, three of which are indicative of mesotrophic conditions (i.e. Potamogeton acutifolius, Ranunculus circinatus, and Fontinalis antipyretica). This is contrasted by the two aquatic species gained, which are indicative of more eutrophic conditions. Other species gained reflect ongoing succession: Three new species from the bog biotope document this late-successional stage in 1987. Four new trees and shrubs (vs. two disappearing), and three new mosses living on dead wood, reflect maturation of carr forests.

Also, ten new species typical of fertile grasslands were recorded. However, relevance to a general trend is unclear as these species all stem from a single recording of a site that had been converted to a meadow by adding soil. Eight other new species are generalist species of field margins and ditch banks; these species probably reflect eutrophication, presumably from atmospheric $\mathrm{N}$ deposition. Polytrichum commune is promoted by high $\mathrm{NH}_{\mathrm{y}}$ deposition levels (Paulissen et al. 2004). Overall, the total number of species recorded in 1944 and in 1987 is equal. However, 26 species of interest to fen conservation are lost, while only 13 species of interest are gained.

Combining all three levels at which vegetation has been studied we conclude that vegetation preservation of the reed sere was successful, but preservation of the quagfen sere largely failed between 1944 and 1993, in spite of unabated groundwater discharge and continued mowing. The landscape changed from a highly diverse area with nearly equal proportions of forest-, water-, semi-aquatic-, and tall-herb vegetation in 1944, into a forest interspersed with water bordered by semi-aquatic vegetation in 1993, with a major change between 1960 and 1975. Around 1960, supply of Vecht water killed off Chara vegetation in lake Loosdrecht (Leentvaar \& Mörzer Bruijns 1962), while from 1965 on groundwater discharge in Suikerpot was reduced. This suggests the loss of rich fen vegetation is due to changes in surface water chemistry, due to either or both of these causes. 
The observed reduction of rich fen bryophytes and increase of more generalist species is in agreement with earlier studies (Barendregt et al. 1990; Fojt \& Harding 1995). And increased forest cover was documented in the Vecht river plain before, in the Naardermeer wetland reserve and in Loosdrecht (Barendregt et al. 1990; 1995). However, these studies also documented the near-disappearance of all (semi-)aquatic vegetation, which was not the case in Het Hol. Also, in the case of the Naardermeer rich fen vegetation was replaced by poor fen vegetation and most reedlands were acidified. In both the Loosdrecht and the Naardermeer cases disappearance of (semi-) aquatic vegetation was attributed to changing surface water chemistry. It seems that vegetation in the Naardermeer was better preserved than in Loosdrecht, and still better in Het Hol. This suggests surface water chemistry was less of a problem in the Naardermeer than in Loosdrecht, and less still in Het Hol. Moreover, vegetation development in the Naardermeer closely resembles that in a fen area in the North of The Netherlands (van Diggelen et al. 1996), and fens in that region have been shown to be affected by acidification rather than by eutrophication (Bootsma $\&$ Wassen 1996). Combined with the increase of Sphagna and lowered water tables in Naardermeer (in contrast to situations in Loosdrecht and $\mathrm{Het} \mathrm{Hol}$ ) this suggests that the Naardermeer is affected by acidification, while Loosdrecht and Het $\mathrm{Hol}$ are less affected. This could explain differences in vegetation development in Naardermeer, Loosdrecht and Het Hol.

\section{Periodic mowing and surface water composition}

Our statistical analysis shows that discharge and periodic mowing have a positive effect on species richness: Within the periodically mown sites discharge is positively correlated with increasing species numbers, and vice versa. The correlation of mowing is weaker, therefore hydrology appears to have a stronger effect than mowing, which confirms conclusions from earlier work (Fojt \& Harding 1995; van Diggelen et al. 1996).

Comparison of surface water composition in lake Gat van de Zandheuvel in the summer of 1950 with that of the summer of 1987 indicates some acidification, probably as a result of increased atmospheric deposition. Unchanged $\mathrm{Cl}$-concentrations indicate that the water balance has not changed substantially. However, lake Gat van de Zandheuvel has become less rich in minerals, with reduced $\mathrm{Fe}-, \mathrm{HCO}_{3^{-}}$, and $\mathrm{Mg}$-concentrations, which is consistent with the reduced minerotrophy of surface water inputs from the Suikerpot area. Most remarkably, inorganic $\mathrm{N}\left(\mathrm{NO}_{3}\right.$ and $\left.\mathrm{NH}_{4}\right)$ is reduced, while $\mathrm{PO}_{4}$ and $\mathrm{SO}_{4}$ concentrations increase. This apparent partial eutrophication cannot be explained from supply of eutrophic surface water or fertilizer inputs, as both would increase $\mathrm{N}$-concentrations as well as $\mathrm{SO}_{4}$ and $\mathrm{PO}_{4}$ concentrations. Also internal eutrophication is unlikely as $\mathrm{HCO}_{3}{ }^{-}$concentration and $\mathrm{pH}$ went down. Finally, atmospheric deposition would mainly boost Nconcentrations.

We suggest that a shift from P- to N-limitation of biomass production has occurred. We hypothesize the following mechanism: In 1950 the productivity of (semi-) aquatic vegetation in $\mathrm{Het} \mathrm{Hol}$ was $\mathrm{P}$-limited; the $\mathrm{N}$ :P ratio was 105, which indicates P-limitation (Güsewell 2004). This is consistent with previous findings that rich fens with Scorpidium scorpioides are mostly P-limited (Kooijman 1993; Boeye et al. 1997; Wassen et al. 2005), although P-limitation of such fens might be a typical nemoral attribute (Øien 2004). Starting from P-limitation, eutrophication increased the availability of $\mathrm{N}$ and $\mathrm{P}$. However, if we assume that eutrophication resulted from Vecht-type water or sewage, this would add P disproportionally to $\mathrm{N}$. Plants typically utilize $\mathrm{N}$ and $\mathrm{P}$ in a 10-20 mg N : $1 \mathrm{mg}$ P ratio (Güsewell 2004), while river Vecht water and sewage contain $\mathrm{N}$ and $\mathrm{P}$ in a $3-7 \mathrm{mg} \mathrm{N}$ : $1 \mathrm{mg}$ P ratio (Table 2). At some point the P-concentration was raised to such a level that it was no longer limiting productivity. From this moment on N-uptake increased, which reduced the N-concentration, and increased nutrient availability stimulates the growth of taller, more light-competitive species (Boyer \& Wheeler 1989; Lepš 1999; van der Hoek et al. 2004). This results in the disappearance of less competitive species from rich fens and their precursors, and is consistent with increased reed sere terrestrialization at the expense of quagfen sere terrestrialization.

In the polder Loosdrecht vegetation deterioration was much more dramatic than in Het Hol, because recruitment of (semi-)aquatic vegetation failed altogether. If we compare nutrient concentrations measured in Loosdrecht with those in $\mathrm{Het} \mathrm{Hol}$ it becomes clear that $\mathrm{PO}_{4}$-concentrations were already a factor five higher in Loosdrecht in 1962 (Barendregt et al. 1990) than in Het Hol in 1987. Also, N:P ratios in Loosdrecht changed from 13 to three in one area, and from 27 to two in the other, indicating that the first area was already $\mathrm{N}$-limited, while the second presumably was $\mathrm{P}$-limited but close to $\mathrm{N}$-limitation. Therefore, it seems that the cases of Het Hol and Loosdrecht represent different levels of eutrophication from which a general response of groundwater fed fens to surface water eutrophication can be inferred. We hypothesize that, starting from a P-limited system - in the (semi-)aquatic stages - eutrophication shifts the system from P- to N-limitation. This results in a shift from quagfen sere terrestrialization to reed sere terrestrialization, in which no new rich fen is formed. Further eutrophication eventually halts all recruitment of (semi-) aquatic vegetation, which ends all 
terrestrialization. In such a collapsed system ongoing succession will drive the entire area to its climax state; carr forest or ultimately bog.

Ideally, a detailed analysis of vegetation change related to environmental factors is performed on permanent plot data (Bakker et al. 1996). However, to our knowledge such data sets are not available for fens at long time scales. Therefore, we have to bring together relevant information from different sources, and the resultant data set may be unsuitable for detailed analysis. However, with cautious interpretation the general trends can be deduced from it, and these can gain validity if multiple sources lead to the same conclusion. Such is the case, for instance, with the hydrological simulation of cross-section 1 and hydraulic head measurements in 1987 both identifying the same area as 'discharge area'. Therefore, in spite of the methodological issues that complicate this kind of research, we feel confident about our conclusions. These are that in this study, as in others, unabated groundwater discharge and continued mowing are important for long-term fen vegetation preservation. However, even when these conditions are met, only slight surface water eutrophication can lead to the demise of rich fen vegetation, probably through a shift from P- to N-limitation. Stronger eutrophication can even halt terrestrialization altogether.

\section{Implications for management}

Our results stress the importance of preventing eutrophication for preservation of fen vegetation in general, and rich fen in particular. Rich fen preservation is doomed even with slight eutrophication, and this cannot be compensated for by mowing. Hence, avoiding contact between nature reserves and the surrounding surface water system deserves more attention. Closing off of connections to the surrounding surface water system can lead to desiccation, and thus acidification. However, some degree of acidification seems preferable to increased nutrient availability. Moreover, in many NWEuropean regions $\mathrm{S}$ - and $\mathrm{NO}_{\mathrm{x}}$-deposition levels are dropping, which reduces acidification. Also, $\mathrm{NH}_{4}{ }^{+}$-poisoning will remain a problem so long as $\mathrm{N}$-emissions from livestock-keeping are not reduced. The best answer to the resultant rapid deterioration of rich fen vegetation seems to be enhanced new formation, which is dependent on surface water quality.

Acknowledgements. TNO-NITG (Built Environment and Geosciences), Utrecht, supplied hydraulic head data. The Dutch Society for the Preservation of Nature kindly allowed us to study their archives. The Water Management and Sewage Service (DWR) in Amsterdam supplied data on sewage composition. Arnoud Molenaar helped with hydrological simulations.

\section{References}

Anon. 1996. Beheerplan Vechtplassen. Vereniging Natuurmonumenten, 's-Graveland, NL. (In Dutch.)

Anon. 2002. SPSS for Windows version 11.5.0. SPSS Inc, Cary, NC, US.

Bakker, J.P., Olff, H., Willems, J.H. \& Zobel, M. 1996. Why do we need permanent plots in the study of long-term vegetation dynamics? J. Veg. Sci. 7: 147-156.

Barendregt, A., Wassen, M.J. \& de Smidt, J.T. 1993. Hydroecological modelling in a polder landscape: a tool for wetland management. In: Vos, C.C. \& Opdam, P.F.M. (eds.) Landscape ecology of a stressed environment, pp. 79-99. Chapman \& Hall, London, UK.

Barendregt, A., Wassen, M.J. \& van Leerdam, A. 1990. Nivellering van de verlanding, een gevolg van veranderingen in hydrologie en beheer. Landschap 7: 17-32. (In Dutch, with English summary.)

Barendregt, A., Wassen, M.J. \& Schot, P.P. 1995. Hydrological systems beyond a nature reserve, the major problem in wetland conservation of Naardermeer. Biol. Conserv. 72: 393-405.

Boeye, D., Verhagen, B., van Haesebroeck, V. \& Verheyen, R.F. 1997. Nutrient limitation in species-rich lowland fens. J. Veg. Sci. 8: 415-424.

Bogaers, P.B.P.M., Prins, J. \& Wiertz, J. 1976. De vegetatie van het Hol en de Suikerpot. Report Instituut voor Systematische Plantkunde Utrecht, NL. (In Dutch.)

Bootsma, M.C. \& Wassen, M.J. 1996. Environmental conditions and fen vegetation in three lowland mires. Vegetatio 127: $173-189$.

Bouman, A.C. 2002. De Nederlandse Veenmossen. Flora en verspreidingsatlas van de Nederlandse Sphagnopsida. KNNV \& A.C. Bouman, Eindhoven, NL. (In Dutch.)

Boyer, M.L.H. \& Wheeler, B.D. 1989. Vegetation patterns in spring-fed calcareous fens: Calcite precipitation and constraints on fertility. J. Ecol. 77: 597-609.

Britto, D.T., Siddiqi, M.Y., Glass, A.D.M. \& Kronzucker, H.J. 2001. Futile transmembrane $\mathrm{NH}_{4}{ }^{+}$cycling: A cellular hypothesis to explain ammonium toxicity in plants. Proc. Natl. Acad. Sci. USA 98: 4255-4258.

de Smidt, J., Krul, H., van der Hoek, D. \& van Raam, J.C. 1979. Bodem en water. Instituut voor Systematische Plantkunde,Utrecht, NL. (In Dutch.)

den Held, A.J., Schmitz, M. \& van Wirdum, G. 1992. Types of terrestrializing fen vegetation in the Netherlands. In: Verhoeven, J.T.A. (ed.) Fens and bogs in the Netherlands: Vegetation, history, nutrient dynamics and conservation, pp. 237-321. Kluwer Academic, Dordrecht, NL.

Eerens, H. C., van Dam, J.D., Beck, J.P., Dolmans, J.H.J., van Pul, W.A.J., Sluyter, R.B.C., van Velze, K. \& Vissenberg, H.A. 2001. Grootschalige luchtverontreiniging en depositie in de Nationale Milieuverkenning 5. RIVM report 408129 016 / 2001, Bilthoven, NL. (In Dutch.)

Fojt, W.J. \& Harding, M. 1995. Thirty years of change in the vegetation communities of three valley mires in Suffolk, England. J. Appl. Ecol. 32: 561-577.

Giller, K.E. \& Wheeler, B.D. 1986. Past peat cutting and present vegetation patterns in an undrained fen in the Norfolk Broadland. J. Ecol. 74: 219-247. 
Godwin, H. \& Turner, J.S. 1933. Soil acidity in relation to vegetation succession in Calthorpe Broad, Norfolk. $J$. Ecol. 21: 235-262.

Gorter,H.P. 1956. Vijftig jaar "Natuurmonumenten”. In: Vijftig jaar natuurbescherming in Nederland, pp. 11-66. Vereeniging Natuurmonumenten, Amsterdam, NL. (In Dutch.)

Güsewell, S. 2004. N: P ratios in terrestrial plants: variation and functional significance. New Phytol. 164: 243-266.

Hogg, P., Squires, P. \& Fitter, A.H. 1995. Acidification, nitrogen deposition and rapid vegetational change in a small valley mire in Yorkshire. Biol. Conserv. 71: 143-153.

Kooijman, A.M. 1992. The decrease of rich fen bryophytes in The Netherlands. Biol. Conserv. 59: 139-143.

Kooijman, A.M. 1993. Causes of the replacement of Scorpidium scorpioides by Calliergonella cuspidata in eutrophicated rich fens 1. Field studies. Lindbergia 18: 78-84.

Küppers, J. 1949. Provinciale almanak voor Utrecht. Samsom n.v., Alphen aan den Rijn, NL. (In Dutch.)

Küppers, J. 1963. Provinciale almanak voor Utrecht. Samsom n.v., Alphen aan den Rijn, NL. (In Dutch.)

Lamers, L.P.M., Tomassen, H.B.M. \& Roelofs, J.G.M. 1998. Sulfate-induced eutrophication and phytotoxicity in freshwater wetlands. Environ. Sci. Technol. 32: 199-205.

Leentvaar,P.\& Mörzer Bruijns, M.F. 1962. De verontreiniging van de Loosdrechtse plassen en haar gevolgen. Levende Nat. 65: 42-48. (In Dutch.)

Lepš, J. 1999. Nutrient status, disturbance and competition: an experimental test of relationships in a wet meadow. J. Veg. Sci. 10: 219-230.

Margadant, W.D. \& During, H.J. 1982. Beknopte flora van Nederlandse blad-en levermossen. Thieme, Zutphen, NL. (In Dutch.)

Meijer, W. \& de Wit, R.J. 1955. Kortenhoef. Een veldbiologische studie van een Hollands verlandingsgebied. Commissie voor de Vecht en het Oostelijk en Westelijk Plassengebied, Amsterdam, NL. (In Dutch.)

Øien, D.I. 2004. Nutrient limitation in boreal rich-fen vegetation: A fertilization experiment. Appl. Veg. Sci. 7: 119132 .

Paulissen, M.P.C.P., van der Ven, P.J.M., Dees, A.J. \& Bobbink, R. 2004. Differential effects of nitrate and ammonium on three fen bryophyte species in relation to pollutant nitrogen input. New Phytol. 164: 451-458.

Pons, L.J. 1992. Holocene peat formation in the lower parts of the Netherlands. In: Verhoeven, J.T.A. (ed.) Fens and bogs in the Netherlands: Vegetation, history, nutrient dynamics and conservation, pp. 7-79. Kluwer Academic, Dordrecht, NL.

Roelofs, J.G.M. 1991. Inlet of alkaline river water into peaty lowlands: effects of water quality and Stratoides aloides L. stands. Aquat. Bot. 39: 267-293.

Schaminée, J.H.J., Stortelder, A.H.F., Westhoff, V., Weeda, E.J. \& Hommel, P.W.F.M. 1995-1999. De vegetatie van Nederland. Opulus Press, Uppsala, SE. (In Dutch.)

Schot, P.P. \& Molenaar, A. 1992. Regional changes in groundwater flow patterns and effects on groundwater composition. J. Hydrol. 130: 151-170.

Schot, P.P., Dekker, S.C. \& Poot, A. 2004. The dynamic form of rainwater lenses in drained fens. J. Hydrol. 293: 74-84.

Siebel, H.N. \& Bijlsma, R.J. 2004. Corrections to the proposal for the Dutch Red List of threatened bryophytes (Buxbaumiella 54). Buxbaumiella 68: 56-64.

Sjörs, H. 1950. On the relation between vegetation and electrolytes in North Swedish mire waters. Oikos 2: 241-258.

van der Hoek, D., van Mierlo, A.J.E.M. \& van Groenendael, J.M. 2004. Nutrient limitation and nutrient-driven shifts in plant species composition in a species-rich fen meadow. $J$. Veg. Sci. 15: 389-396.

van der Maarel, E. 1979. Transformation of cover-abundance values in phytosociology and its effects on community similarity. Vegetatio 39: 97-114.

van der Meijden, R. 1996. Heukels' Flora van Nederland. 22nd. ed. Wolters-Noordhoff, Groningen, NL. (In Dutch.)

van der Meijden, R., Odé, B., Groen, C.L.G., Witte, J.-P.M. \& Bal, D. 2000. Bedreigde en kwetsbare vaatplanten in Nederland, basisrapport met voorstel voor de Rode Lijst. Gorteria 26: 85-208. (In Dutch.)

van Diggelen, R., Molenaar, W.J. \& Kooijman, A.M. 1996. Vegetation succession in a floating mire in relation to management and hydrology. J. Veg. Sci. 7: 809-820.

van Elburg, H., Engelen, G.B. \& Hemker, C.J. 1989. FLOWNET: computerprogram for modelling two-dimensional stationary groundwater flow in an inhomogeneous anisotropic section version 5.1. Institute for Earth Sciences, Free University, Amsterdam, NL.

van Tongeren, O. 1986. FLEXCLUS, an interactive program for classification and tabulation of ecological data. Acta Bot. Neerl. 35: 137-142.

van Wirdum, G., den Held, A.J. \& Schmitz, M. 1992. Terrestrializing fen vegetation in former turbaries in the Netherlands. In: Verhoeven, J.T.A. (ed.) Fens and bogs in the Netherlands: vegetation, history, nutrient dynamics and conservation, pp. 323-360. Kluwer Academic, Dordrecht, NL

Verhoeven, J.T.A., Kemmers, R.H. \& Koerselman, W. 1993. Nutrient enrichment of freshwater wetlands. In: Vos, C.C. \& Opdam, P.F.M. (eds.) Landscape ecology of a stressed environment, pp. 33-59. Chapman and Hall, London, UK.

Wassen, M.J., Barendregt, A., Bootsma, M.C. \& Schot, P.P. 1989. Groundwater chemistry and vegetation of gradients from rich fen to poor fen in the Naardermeer (the Netherlands). Vegetatio 79: 117-132.

Wassen, M.J., Olde Venterink, H., Lapshina, E.D. \& Tanneberger, F. 2005. Endangered plants persist under phosphorus limitation. Nature 437: 547-550.

Westhoff, V., Bakker, P. A. \& van Leeuwen, C. G. 1971. Het lage land. Vereniging tot behoud van Natuurmonumenten in Nederland, Amsterdam, NL. (In Dutch.)

Wheeler, B.D. 1993. Botanical diversity in British mires. Biodivers. Conserv. 2: 490-512.

Zar, J.H. 1984. Biostatistical analysis. Prentice-Hall, Englewood Cliffs, NJ, US.

Received 5 November 2005; Accepted 1 June 2006; Co-ordinating Editor: J. Pfadenhauer.

For Apps. 1-3, see also JVS/AVS Electronic Archives; www.opuluspress.sel 
App. 1. Synoptic table of vegetation types. Frequency of occurrence (in normal script) as percentage, and average cover (in superscript) in classes: $-=0-5 \%,+=5-10 \%, \mathrm{I}=10-20 \%, \mathrm{II}=20-40 \%, \mathrm{III}=40-60 \%, \mathrm{IV}=60-80 \%$, and V $=80-100 \%$.

Vegetation type

No. of relevés in 1944

No. of relevés in 1987

Total no. of species
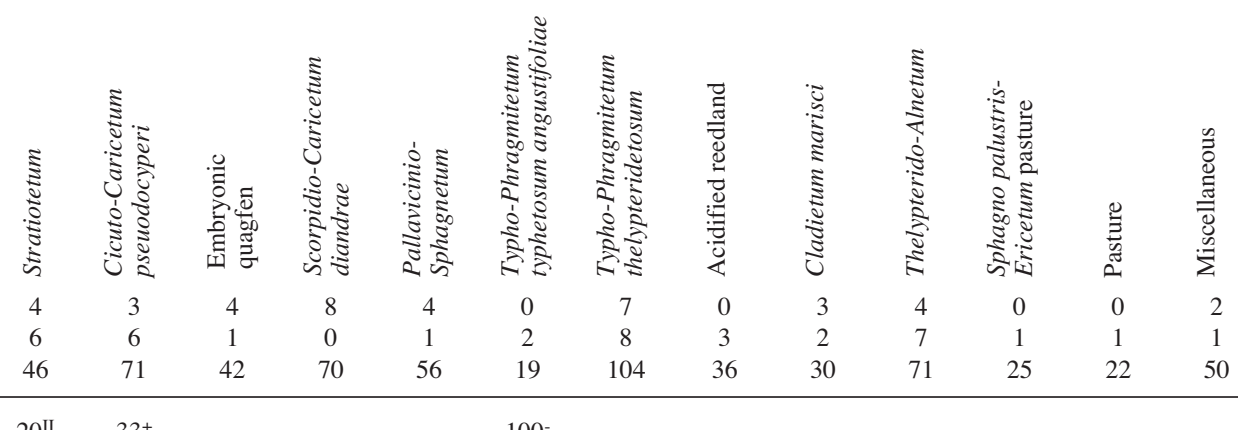

Ceratophyllum demersum

$\begin{array}{ll}20^{\mathrm{II}} & 33 \\ 50^{-} & \\ 70^{-} & 11\end{array}$

Elodea canadensis

Myriophyllum spicatum

Ranunculus circinatus

Myriophyllum verticillatum

Hydrocharis morsus-ranae

Potamogeton lucens

Nuphar lutea

Nymphaea alba

Stratiotes aloides

Utricularia vulgaris

Hottonia palustris

Potamogeton obtusifolius

Potamogeton acutifolius

Eleocharis palustris

Juncus bulbosus

Lemna trisulca

Lemna minor

Spirodela polyrhiza

Fontinalis antipyretica

Sphagnum spec.

Riccia fluitans

Drepanocladus aduncus

Ricciocarpos natans

Rumex hydrolapathum

Berula erecta

Sparganium erectum

Lycopus europaeus

Alisma plantago-aquatica

Rorippa amphibia

Glyceria maxima

Acorus calamus

Iris pseudacorus

Typha latifolia

Mentha aquatica

Calla palustris

Cicuta virosa

Carex pseudocyperus

Ranunculus lingua

Epilobium hirsutum

Myosotis scorpioides

Schoenoplectus lacustris

Sparganium emersum

Schoenoplectus tabernaemontani

Wolffia arrhiza

Bidens tripartita

Stachys palustris

Rorippa palustris

Galium palustre

Phragmites australis

Typha angustifolia

Caltha palustris

Poa trivialis

Thelypteris palustris

$\begin{array}{llll}70^{-} & 11^{-} & 20^{-} & \\ 30^{\mathrm{I}} & & 20^{-} & \\ 20^{-} & & & 8 \\ 10^{-} & & 40^{-} & 8\end{array}$

$\begin{array}{cccc}10^{-} & & 40^{-} & \\ 80^{+} & 89^{-} & 100^{+} & 50^{+}\end{array}$

$10^{\mathrm{I}}$

$40-$

$40^{-}$

$100^{\mathrm{II}}$

44

$11^{-}$

$40^{-} \quad 25^{-}$

$100^{-} \quad 25^{-}$

$100^{-}$

$50^{-} \quad 7^{-}$

$20^{-}$

$50^{+}$

\begin{tabular}{|c|c|c|c|}
\hline $90^{-}$ & $44^{-}$ & $20^{-}$ & \\
\hline $10^{+}$ & $33^{-}$ & $40^{+}$ & \\
\hline $70^{-}$ & $33^{-}$ & $80^{-}$ & \\
\hline $10^{-}$ & & $20^{-}$ & \\
\hline \multirow[t]{4}{*}{$30^{-}$} & & $60^{-}$ & \\
\hline & $11^{-}$ & $20^{-}$ & \\
\hline & & $20^{-}$ & \\
\hline & & $20^{-}$ & \\
\hline $10^{-}$ & $67^{-}$ & & \\
\hline $10^{-}$ & $22^{-}$ & $20^{-}$ & \\
\hline $10^{-}$ & $44^{-}$ & $20^{-}$ & \\
\hline $10^{-}$ & $67^{-}$ & $20^{-}$ & 38 \\
\hline \multirow[t]{3}{*}{$20^{-}$} & $33^{-}$ & $20^{-}$ & $25^{-}$ \\
\hline & $11^{-}$ & & \\
\hline & & $20^{-}$ & \\
\hline
\end{tabular}

$\begin{array}{cccc} & & & 9^{-} \\ 100^{-} & 13^{-} & 20^{-} & \\ 50^{-} & 20^{-} & 40^{+} & 9^{-} \\ 100^{-} & 13^{-} & 60^{-} & \end{array}$

$50^{-}$

$\begin{array}{cc} & 27^{-} \\ 100^{-} & 20^{-} \\ & 73^{-} \\ 13^{-}\end{array}$

$20^{-}$

$7^{-}$

$$
40-
$$

$33^{-}$

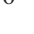

$33^{-}$

$33^{+}$

$33-$

$10^{-}$

$20^{-}$

$38^{-}$

$67^{-}$

$20^{-}$

$27^{-}$

$33^{-}$

$100^{-}$

$33^{-}$

$60^{-}$

$20^{-}$

$33^{-}$

$33^{+}$

$40^{-}$

$100^{-}$

App. 1-3. Internet supplement to: van Belle, J.; Barendregt, A. \& Schot, P.P.; Wassen, M.J. 2006.

The effects of groundwater discharge, mowing and eutrophication on fen vegetation evaluated over half a century.

Appl. Veg. Sci. 9: 195-204. 
App. 1, cont.

Vegetation type

No. of relevés in 1944

No. of relevés in 1987

Total no. of species

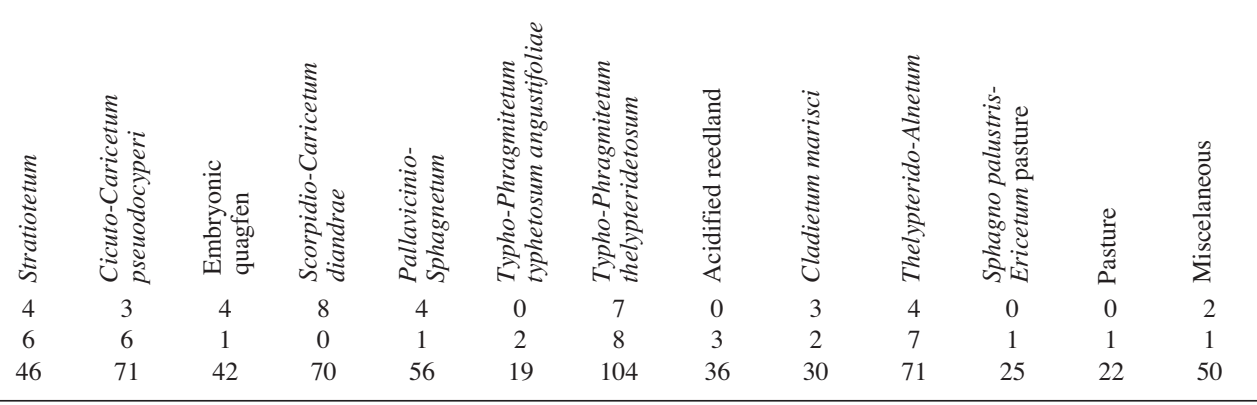

Eupatorium cannabinum

Peucedanum palustre

Brachythecium rutabulum

Dactylorhiza majalis ssp. praetermissa

Filipendula ulmaria

Chiloscyphus polyanthos

Marchantia polymorpha

Hypericum tetrapterum

Leptodictyum kochii

Plagiomnium affine

Lychnis flos-cuculi

Calystegia sepium

Hypnum cupressiforme

Dryopteris dilatata

Lathyrus palustris

Dryopteris carthusiana

Plagiomnium spec.

Angelica sylvestris

Calliergon cordifolium

Lysimachia thyrsiflora

Carex riparia

Cladium mariscus

Carex paniculata

Salix viminalis

Carex rostrata

Carex oederi

Liparis loeselii

Bryum pseudotriquetrum

Campylium stellatum

Campylium polygamum

Fissidens adianthoides

Riccardia multifida

Riccardia chamedryfolia

Sphagnum contortum

Campylium elodes

Carex diandra

Scorpidium scorpioides

Pellia neesiana

Calliergon giganteum

Menyanthes trifoliata

Equisetum fluviatile

Carex lasiocarpa

Utricularia minor

Juncus subnodulosus

Chara spec.

Riccardia pinguis

Epilobium parviflorum

Pellia epiphylla

Hydrocharis morsus-ranae

Calliergonella cuspidata

Epilobium palustre

Juncus articulatus

Pedicularis palustris

Hammarbya paludosa

Lythrum salicaria

Potentilla palustris

Agrostis canina

Viola palustris

$\begin{array}{llll}78^{-} & & & 40^{-} \\ 78^{-} & 60^{-} & 50^{-} & 80^{-} \\ 11^{-} & 20^{-} & & \\ & & 20^{-} & \end{array}$

$11^{-}$

$11^{-}$

$\begin{array}{cccc} & 11^{-} & & 25^{-} \\ 10^{-} & 22^{-} & 60^{-} & 38^{-} \\ & 11^{-} & & 25^{-} \\ 10^{-} & 56^{+} & & 38^{\text {II }} \\ & 78^{-} & & \\ & & & \\ 10^{-} & 11^{-} & 80^{\mathrm{I}} & 25^{-}\end{array}$

$20^{-}$

$11^{-}$

$11^{+} \quad 20^{-}$

$20^{-}$

$50^{-} \quad 7$

$\begin{array}{cc}67^{-} & 18 \\ 33^{+} & 9^{-}\end{array}$

$33^{-}$

$13^{-}$

$20^{-}$

7

$33^{-}$

33

$33^{-} \quad 20^{-}$

$33^{-}$

$13^{-}$

$27^{-}$

$40^{-}$
$20^{-}$

$20^{-}-50^{-}$

$60^{-}$

67

$\begin{array}{ll}50^{-} & 47^{+} \\ & 53^{-}\end{array}$

$40^{-}$

$67^{-} \quad 40^{-}$

$100^{\mathrm{IV}}$

$18^{-}$

$18^{-}$

9 -

$20^{-}$

$20^{-} \quad 9^{-}$

$20^{-}$

$33^{-}$

$27^{\mathrm{I}}$

$20^{-}$

$20^{-}$

$20^{-}$

$20^{-}$

7

$80^{-}$

$20^{-}$

$11^{-}$

$63^{\text {II }}$

$13^{-}$

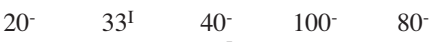

$80^{-}$
$60^{-}$

$60^{-}$
$100^{-}$

$20^{-}$

$60^{+}$

$20^{-}$

$11^{-} \quad 20^{-}$

$11^{-} \quad 20^{-}$

$25^{-}$

$100^{-}$

$40^{-}$

40

$20^{-}$

$100^{-}$

$80^{-}$

$100^{+}$

$80^{-}$

App. 1-3. Internet supplement to: van Belle, J.; Barendregt, A. \& Schot, P.P.; Wassen, M.J. 2006.

The effects of groundwater discharge, mowing and eutrophication on fen vegetation evaluated over half a century.

Appl. Veg. Sci. 9: 195-204. 
App. 1, cont.

Vegetation type

No. of relevés in 1944

No. of relevés in 1987

Total no. of species

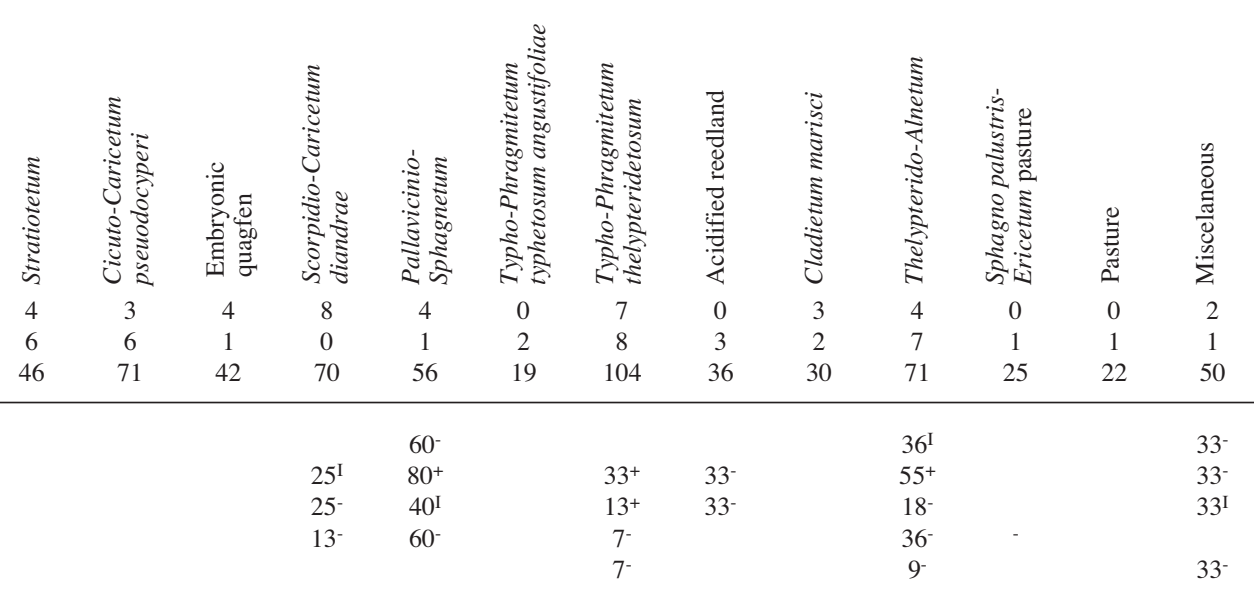

Sphagnum fimbriatum

Sphagnum squarrosum

Sphagnum subnitens

Aulacomnium palustre

Dryopteris cristata

Pallavicinia lyellii

Dicranum bonjeanii

Carex curta

Carex echinata

Juncus filiformis

Drosera rotundifolia

Pohlia nutans

Sphagnum flexuosum s.1.

Sphagnum palustre

Calypogeia fissa

Stellaria palustris

Potentilla erecta

Lysimachia vulgaris

Succisa pratensis

Calamagrostis canescens

Carex panicea

Galium uligunosum

Eriophorum spec.

Holcus lanatus

Juncus conglomeratus

Sphagnum capillifolium

Calypogeia trichomanis

Alnus glutinosa

Salix cinerea

Betula pubescens

Sorbus aucuparia

Viburnum opulus

Salix aurita

Myrica gale

Betula pendula

Mnium hornum

Solanum dulcamara

Cirsium palustre

Scutellaria galericulata

Lophocolea bidentata

Lophocolea heterophylla

Cardamine pratensis

Carex acutiformis

Lonicera periclymenum

Rubus spec.

Populus tremula

Rhamnus frangula

Aronia $\times$ prunifolia

Campylopus fragilis

Epilobium spec.

Betula spec.

Plagiothecium denticulatum

Eurhynchium praelongum

Plagiomnium rostratum

Bryum spec.

Erica tetralix

Cephalozia connivens

Sphagnum magelanicum

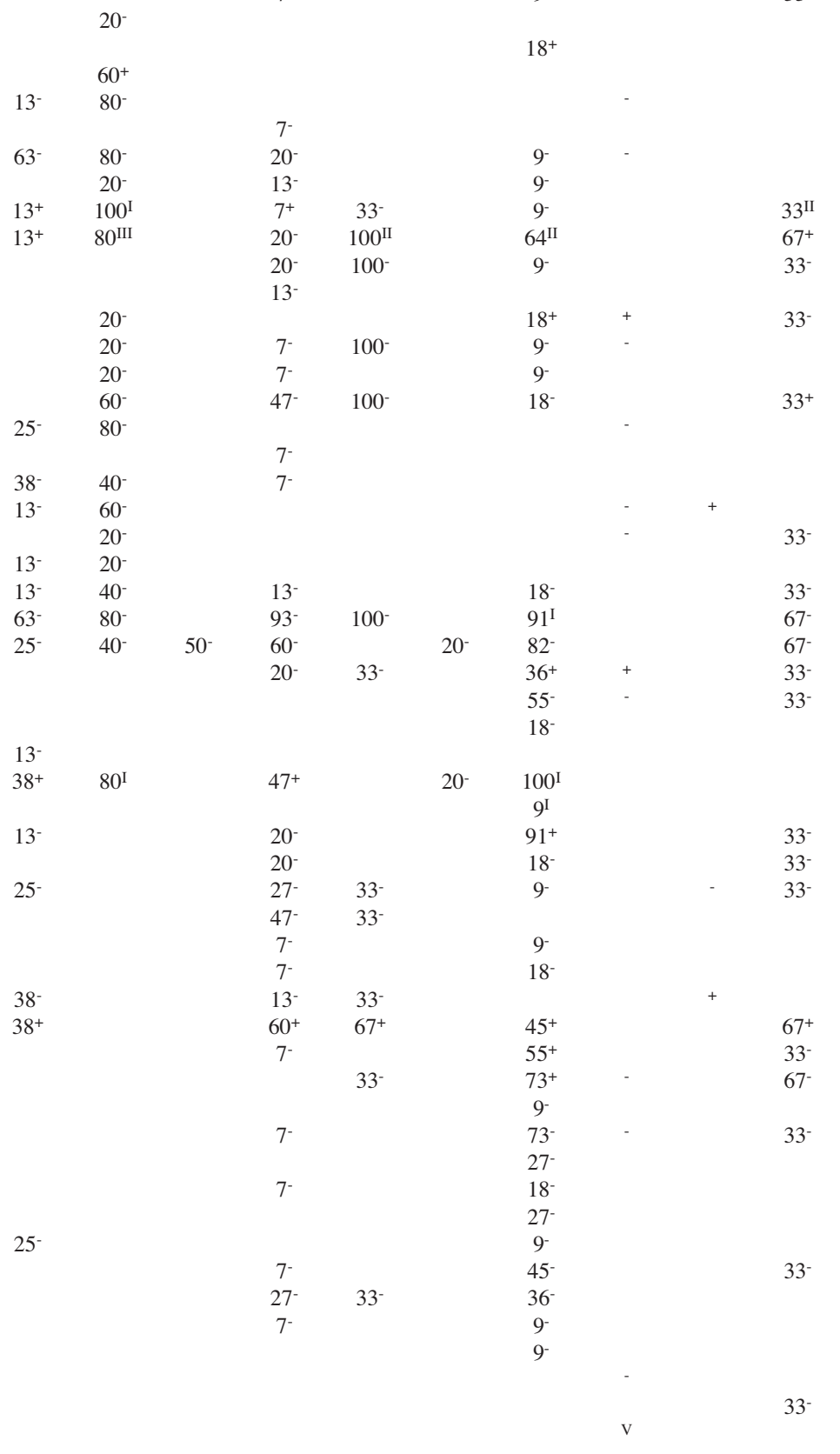

App. 1-3. Internet supplement to: van Belle, J.; Barendregt, A. \& Schot, P.P.; Wassen, M.J. 2006. 
App. 1, cont.

Vegetation type

No. of relevés in 1944

No. of relevés in 1987

Total no. of species

\begin{tabular}{|c|c|c|c|c|c|c|c|c|c|c|c|c|}
\hline 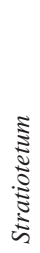 & 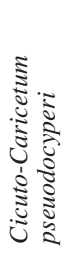 & 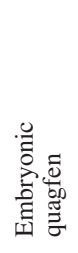 & 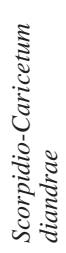 & 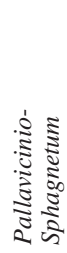 & 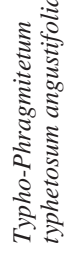 & 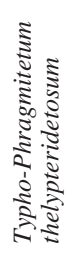 & 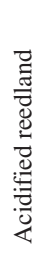 & 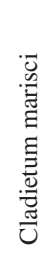 & 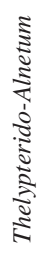 & 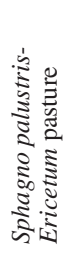 & $\begin{array}{c}\mathscr{\Xi} \\
\stackrel{\Xi}{0} \\
\tilde{\Xi}\end{array}$ & 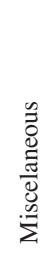 \\
\hline 4 & 3 & 4 & 8 & 4 & 0 & 7 & 0 & 3 & 4 & 0 & 0 & 2 \\
\hline 6 & 6 & 1 & 0 & 1 & 2 & 8 & 3 & 2 & 7 & 1 & 1 & 1 \\
\hline 46 & 71 & 42 & 70 & 56 & 19 & 104 & 36 & 30 & 71 & 25 & 22 & 50 \\
\hline
\end{tabular}

Anthoxanthum odoratum

Polytrichum commune

Molinia caerulea

$40^{-}$

Luzula multiflora

$13^{-} \quad 20^{+}$

7

Juncus effusus

Rumex acetosa

Lolium perenne

Poа аппиа

Trifolium pratense

Plantago lanceolata

Ranunculus repens

Glechoma hederacea

Stellaria media

Ranunculus acris

Taraxacum officinale

Rumex obtusifolius

App. 2. Species that were recorded in 1944, but not in 1987, ordered by habitat. Explanation of symbols and units: ${ }^{1}$ plant type: $\mathrm{m}=$ moss, $\mathrm{v}=$ vascular plant, $\mathrm{s}=$ stonewort ${ }^{2}$ Dutch Red List status: $\mathrm{VU}=$ vulnerable, $\mathrm{CR}=$ critical; ${ }^{3}$ habitat each species typically occurs in in the study region; ${ }^{4}$ frequency of occurrence as percentage of all 39 recordings (in normal script); ${ }^{5}$ average cover in classes (in superscript): $-=0-5 \%,+=5-10 \%, \mathrm{I}=10-20 \%, \mathrm{II}=20-40 \%, \mathrm{III}=40-60 \%, \mathrm{IV}=60-80 \%$, and V $=80-100 \%$.

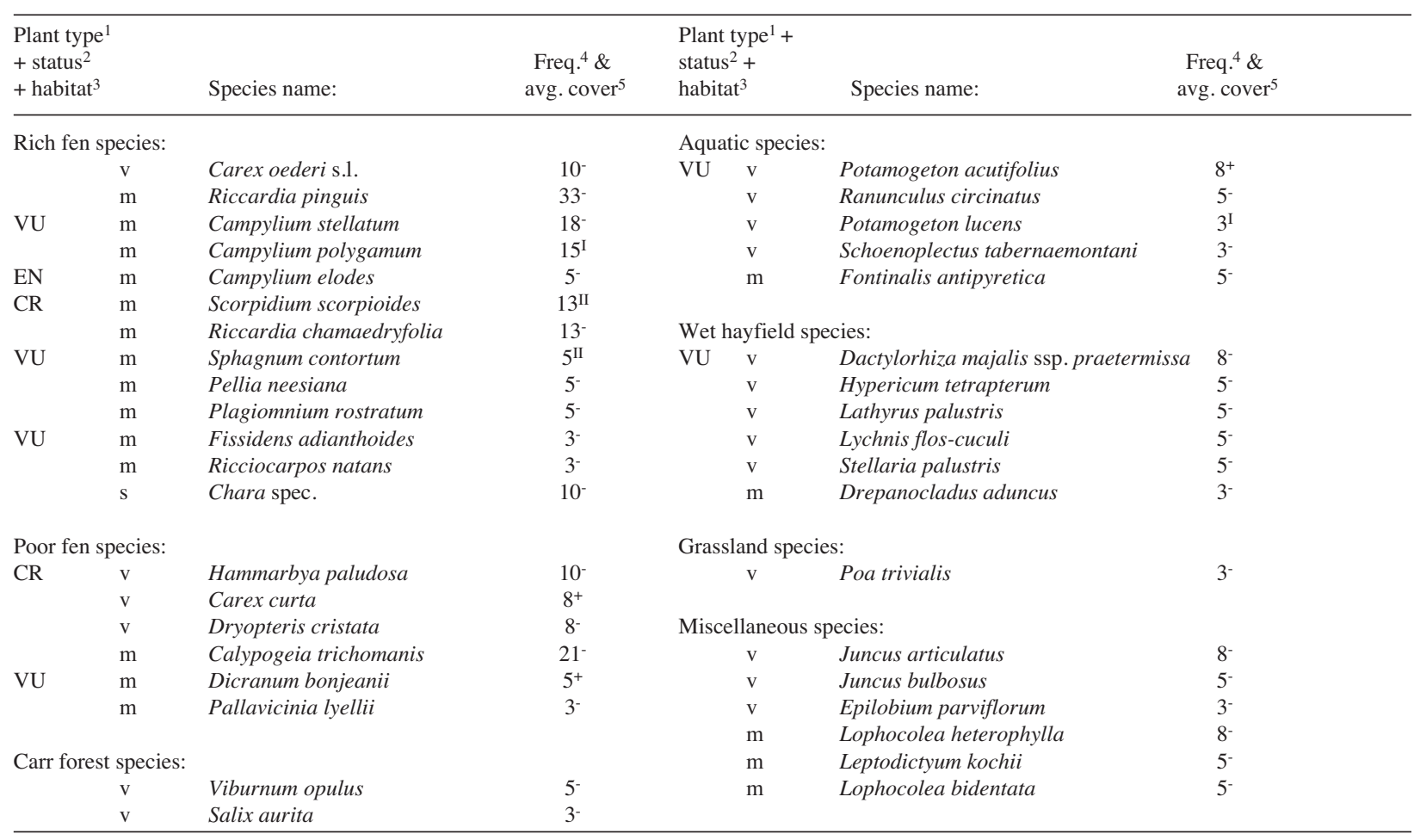

App. 1-3. Internet supplement to: van Belle, J.; Barendregt, A. \& Schot, P.P.; Wassen, M.J. 2006. 
App.3. Species that were recorded in 1987, but not in 1944, ordered by habitat. Explanation of symbols and units: ${ }^{1}$ plant type: $\mathrm{m}=$ moss, $\mathrm{v}=$ vascular plant; ${ }^{2}$ Dutch Red List status: VU = vulnerable, EN = endangered; ${ }^{3}$ habitat each species typically occurs in in the study region; ${ }^{4}$ frequency of occurrence as percentage of all 39 recordings (in normal script); ${ }^{5}$ average cover (in superscript) in classes: $-=0-5 \%,+=5-10 \%, \mathrm{I}=10-20 \%, \mathrm{II}=20-40 \%, \mathrm{III}=40-60 \%, \mathrm{IV}=60-80 \%$, and V $=80-100 \%$.

\begin{tabular}{|c|c|c|c|c|c|}
\hline $\begin{array}{l}\text { Plant type } \\
+ \text { status }^{2} \\
+ \text { habitat }^{3}\end{array}$ & Species name: & $\begin{array}{c}\text { Freq. }{ }^{4} \& \\
\text { avg. cover }{ }^{5}\end{array}$ & $\begin{array}{l}\text { Plant type }^{1}+ \\
\text { status }^{2}+ \\
\text { habitat }^{3}\end{array}$ & Species name: & $\begin{array}{c}\text { Freq. }{ }^{4} \& \\
\text { avg. cover }\end{array}$ \\
\hline \multicolumn{3}{|l|}{ Bog species: } & \multicolumn{3}{|c|}{ Aquatic species: } \\
\hline $\mathrm{m}$ & Sphagnum magellanicum & $3^{\mathrm{V}}$ & $\mathrm{v}$ & Ceratophyllum demersum & $18^{\mathrm{I}}$ \\
\hline $\mathrm{v}$ & Erica tetralix & $3^{-}$ & VU & Potamogeton obtusifolius & $13^{\mathrm{I}}$ \\
\hline & & & Carr forest sp & & \\
\hline \multicolumn{3}{|l|}{ Grassland species: } & $\mathrm{V}$ & Aronia x prunifolia & $8^{-}$ \\
\hline $\mathrm{V}$ & Poa annua & $3^{I}$ & $\mathrm{v}$ & Betula pendula & $3^{\mathrm{I}}$ \\
\hline $\mathrm{v}$ & Lolium perenne & $3^{+}$ & $\mathrm{v}$ & Populus tremula & $3-$ \\
\hline $\mathrm{v}$ & Ranunculus repens & $3^{+}$ & $\mathrm{v}$ & Salix viminalis & $3^{-}$ \\
\hline $\mathrm{v}$ & Ranunculus acris & $3^{-}$ & & & \\
\hline $\mathrm{v}$ & Trifolium pratense & $3^{+}$ & Dead wood s & les: & \\
\hline $\mathrm{v}$ & Plantago lanceolata & $3^{+}$ & $\mathrm{m}$ & Calypogeia fissa & $21^{-}$ \\
\hline $\mathrm{v}$ & Rumex obtusifolius & $3^{-}$ & $\mathrm{m}$ & Cephalozia connivens & $3^{-}$ \\
\hline $\mathrm{v}$ & Glechoma hederacea & $3^{+}$ & & & \\
\hline $\mathrm{v}$ & Stellaria media & $3^{-}$ & Fen species: & & \\
\hline & & & $\mathrm{V}$ & Calla palustris & $13^{-}$ \\
\hline \multicolumn{3}{|c|}{ Field margin species: } & EN & Calliergon giganteum & $3^{-}$ \\
\hline $\mathrm{v}$ & Stachys palustris & $23^{-}$ & & & \\
\hline $\mathrm{v}$ & Myosotis scorpioides & $13^{-}$ & \multicolumn{3}{|c|}{ Wet hayfield species: } \\
\hline $\mathrm{v}$ & Angelica sylvestris & $5^{-}$ & $\mathrm{v}$ & Galium uliginosum & $3^{-}$ \\
\hline $\mathrm{v}$ & Bidens tripartita & $5^{-}$ & & & \\
\hline $\mathrm{v}$ & Rorippa amphibia & $3^{-}$ & \multicolumn{3}{|c|}{ Miscellaneous species: } \\
\hline $\mathrm{v}$ & Rorippa palustris & $3^{-}$ & VU $\quad \mathrm{v}$ & Juncus filiformis & $3^{-}$ \\
\hline $\mathrm{v}$ & Sparganium emersum & $3^{-}$ & $\mathrm{v}$ & Dryopteris dilatata & $3^{-}$ \\
\hline $\mathrm{v}$ & Eleocharis palustris & $3^{-}$ & $\mathrm{m}$ & Hypnum cupressiforme & $8^{-}$ \\
\hline & & & $\mathrm{m}$ & Polytrichum commune & $5^{+}$ \\
\hline
\end{tabular}

App. 1-3. Internet supplement to: van Belle, J.; Barendregt, A. \& Schot, P.P.; Wassen, M.J. 2006. 